\title{
The Balkan Investigation
}

\author{
By William Schabas
}

The direct ancestor of the International Criminal Tribunal for the former Yugoslavia - the institution that confirmed the rebirth of international criminal justice - was the Commission of Experts. Comprised of five members, several of them specialists in international law, the Commission's establishment was mandated by the Security Council. Resolution 780, adopted unanimously on 6 October 1992, was charged with investigating 'grave breaches of the Geneva Conventions and other violations of international humanitarian law committed during the conflict in the former Yugoslavia'.

It was the most robust measure that had then been taken by the United Nations in order to deal with a conflict whose beginnings dated back more than a year, and that had featured battles and atrocities over a period of several months as Slovenia and then Croatia broke away from Yugoslavia to became independent states. The worst of the conflict, in Bosnia and Herzegovina, where the three main ethnic groups were more balanced in numbers and where no single one could claim a majority, was only then getting underway. Desperate but unsuccessful political initiatives to address the crisis had been launched since 1991. But it was only in mid-1992 that the Security Council began to use the language of international criminal justice. In August 1992 it adopted a resolution that said perpetrators 'will be individually [held] responsible'.

The August resolution had been provoked by stunning revelations of atrocities in the Omarska concentration camp. The resolution referred to 'reports of mass forcible expulsion and deportation of civilians, imprisonment and abuse of civilians in detention centres, deliberate attacks on non-combatants, hospitals and ambulances, impeding the delivery of food and 
medical supplies to the civilian population, and wanton devastation and destruction of property'.

\section{Early justice initiatives in the Balkans}

This wasn't the first time international law had turned its attention to the Balkans. One of the very earliest international fact-finding or expert commissions of inquiry was set up in 1913, at the dawn of the First World War. An unofficial body backed by the young Carnegie Endowment, it investigated violations in the conflicts that afflicted the territory of what would later be called 'Yugoslavia'. The Commission's report invoked two of the Hague Conventions of 1899 and 1907 as a basis for concluding that war crimes had been perpetrated by various forces in the conflict. Cherif Bassiouni has written that the atrocities documented by the Commission of Experts bear a 'haunting resemblance' to those in the report of the 1913 Carnegie Commission.

After the First World War there were calls for international prosecution of war crimes. A Commission on Responsibilities set up by the Preliminary Peace Congress compiled evidence of atrocities, including rapes, torture, killing of hostages and 'denaturalisation', a notion akin with similarities to what is today the crime of genocide, perpetrated by the Austrians and their allies in the Balkans. Greece, Serbia and Romania managed to convince the Commission that the peace treaty with Bulgaria should provide for an international criminal court to prosecute individual perpetrators. However, the measure was vetoed by the French prime minister after the Americans objected.

And then there was the Nuremberg trial in 1945 and 1946 . It did not focus on the Balkans at such, of course, but in its more general treatment of Nazi atrocity throughout the occupied continent the region was not neglected. The International 
Military Tribunal heard evidence of the mass murder of hostages, perpetrated in Yugoslavia by the Gestapo. In its judgment, it noted Hitler's instruction to his generals that Yugoslavia was to be destroyed with 'unmerciful harshness'.

Thus, when the security Council flagged the perpetration of war crimes in the Balkans in October 1992, the initiative to investigate atrocities in that sorry region was not being cut from whole cloth. International criminal law was only just awakening from its forty-year hibernation. The invasion of Kuwait by Iraq in 1990 had prompted calls for an international criminal tribunal to try the crime of aggression as well as for a fact-finding commission similar to what was called for in Resolution 680, but neither initiative bore fruit. A related idea, that of a 'truth commission', was also starting to appear on the international radar screen. A UN-backed initiative that was led by a distinguished American judge, Thomas Buergenthal, had recently completed its study of atrocities in El salvador. All of this contributed to a context in which, as Victor Hugo wrote, nothing could stop an idea whose time had come.

In August 1992, the Special Rapporteur on the former Yugoslavia who had been appointed by the UN Commission on Human Rights, Tadeusz Mazowiecki, produced a report that proposed the establishment of an international commission of inquiry. Within the Department of State, a young international lawyer, Michael Scharf, was preparing draft language for a security Council resolution whereby such a body would be authorized.

During the negotiations of the text of Resolution 680, the United Kingdom, France and Russia agreed on setting up a factfinding body, but wanted to call it a 'committee'. The United States insisted that the body be called a 'commission', apparently having in mind the precedent of the United Nations War Crimes Commission. That institution had begun its work in London in early 1944 and was seen, then and now, as a precursor of the International Military Tribunal. 


\section{Establishing the Commission of Experts}

Under Resolution 680, the Secretary-General was charged with implementing the will of the Security council. The Resolution did not specify the size of the Commission. Secretary-General Boutros-Ghali chose to appoint a 'Magnificent Five', all of them men, something that would be unthinkable today. Nor did they represent the five geographic groups in the United Nations, as is the tradition, but care was taken to ensure that none of them were from a permanent member of the Security Council

Three of them were distinguished academics: Frits Kalshoven, of Leiden University in the Netherlands, Torkel Opsahl, of the University of Oslo, and Cherif Bassiouni, an Egyptian national working at De Paul University in the United States. Each was a distinguished scholar in what were then still relatively obscure fields, international humanitarian law and international human rights law, at least by comparison with the present day. The other two members of the Commission were William Fenrick, an accomplished Canadian military lawyer, and Keba M'Baye, a Senegalese judge who had served on the International Court of Justice. Kalshoven was named Chairman of the Commission.

The Commission of Experts was frustrated from the start, and throughout its work, both by its lack of appropriate funding and by an apparently uncooperative United Nations bureaucracy characterized by extreme caution and even inertia. But it also had to contend with serious concerns, both within the UN and from powerful states and international personalities, that by focussing upon justice the Commission of Experts might complicate efforts to negotiate peace. Some thought that an effective fact-finding commission, with the means to document violations of international law, could get in the way of 
political compromise.

Even before the Commission first met, it attracted attention from other bodies concerned with investigation of atrocities in the Balkan conflict. Acting upon a report prepared by a three-person committee of the conference on Security and Cooperation in Europe that included the Swedish judge Hans Corell, the Conference's Committee of Senior Officials recommended, in early November 1992, that '[t]he United Nations Commission of Experts should give particular attention to the principle of personal responsibility for war crimes and examine how this principle could be put into practice by an ad hoc tribunal'.

The Commission began meeting in Geneva, in November 1992, in one of the conference rooms of the old Palais des Nations, originally built as the headquarters of the League of Nations. Provided with only limited information from Member states, and without yet having undertaken its own fact-finding, the Commission of Experts focussed on the legal dimension of its task. This was something for which the members were well-suited, given their undoubted and widely acknowledged expertise.

Ironically, as the Commission of Experts was convening in December 1992, the Secretary of State of the United Nations was delivering a dramatic speech in another of the conference rooms down the corridor in the same building. In the final weeks of his cabinet term within the Bush administration, Lawrence Eagleburger named several individuals whom he said should be held personally responsible, including Radovan Karadžić, Ratko Mladić, Slobodan Milošević, Vojislav Šešelj and Adem Delić. They were described as individuals who should be prosecuted for war crimes and, indeed, they all would later stand in the dock before the International Criminal Tribunal for the former Yugoslavia.

In January 1993, the Commission began taking steps to address the inadequacy of its funding. It proposed that the United Nations set up a trust fund into which Member states 
could make voluntary contributions, seemingly simple matter. Lawyers inside the UN opposed the idea, arguing that it had not been specifically contemplated by the security council resolution. In March, the General Assembly agreed to create a trust fund. Almost immediately the United States contributed half a million dollars. Later, under the creative leadership of Cherif Bassiouni, additional resources were tapped from governments as well as from private sources, notably philanthropic foundations with a human rights orientation.

\section{The first interim report}

The Commission of Experts presented it first interim report to the United Nations Security Council in early February 1993. The report attempted a definition of 'ethnic cleansing', a rather new term that was appearing increasingly in journalistic sources, popular accounts and political debates. For the Commission, 'ethnic cleansing' consisted of 'rendering an area wholly homogenous by using force or intimidation to remove persons of given groups from the area'. Its definition was later endorsed by the International court of Justice in its February 2007 judgment in the Bosnia V. Serbia case.

The Commission concluded that 'ethnic cleansing' had been perpetrated 'by means of murder, torture, arbitrary arrest and detention, extra-judicial executions, rape and sexual assaults, confinement of civilian population in ghetto areas, forcible removal, displacement and deportation of civilians, deliberate military attacks or threats of attacks on civilian areas, and wanton destruction of property'. For the Commission, these were both war crimes and crimes against humanity and, potentially, even genocide.

The Resolution 680 Commission of Experts was not the first to use the language of international criminal law to describe the Balkan conflict. But the prestige of its members, and 
especially the great authority they possessed in the relevant areas of international law, cloaked its findings in gravitas. This was not a case of inexpert politicians or journalists throwing around provocative language, often in a demagogic context. Rather, eminent scholars in the field, sitting as members of an official United Nations Commission, had made authoritative preliminary findings.

The February report of the Commission considered the establishment of an ad hoc international criminal tribunal that might be charged with prosecuting the crimes it was then identifying. The Commission of Experts said that 'it would be for the Security Council or another competent organ of the United Nations to establish such a tribunal', adding that such a move would be 'consistent with the direction' that the work of the Commission had taken. The Commission was not the first body to propose an international tribunal, but by adding the weight of its view to the debate, it may well have helped tipped the scales.

Within days, the Security Council adopted Resolution 808 whereby it '[d]ecide[d]' that an international criminal tribunal shall be established for the prosecution of persons responsible for serious violations of international humanitarian law committed in the territory of the former Yugoslavia since 1991'. Three months later, in May 1993, the security Council adopted the Statute of the International Criminal Tribunal for the former Yugoslavia.

Nearly half a century had passed since the establishment of the first generation of international criminal courts, at Nuremberg and Tokyo. In May 1993, nobody would have expected that the Tribunal would only conclude its operations in December 2017, and even then before its prosecutions were entirely finished. A successor institution known as the Mechanism for the International Criminal Tribunals would then be required for the final appeals and retrials, and for future unforeseen 
developments such as the arrest of remaining suspects and the discovery of new evidence.

\section{Laying the groundwork for prosecution}

Adoption of Security Council Resolution 827 in May did not immediately shift the centre of gravity to the new tribunal. It would take nearly a year for the International Criminal Tribunal to become fully operational. Judges were only elected in November 1993, and eight more months would pass before a Prosecutor, Richard Goldstone, took the reins. In the meantime, the Commission of Inquiry pursued its important work. This had been understood by the security council. The preamble of Resolution 827 stated that 'pending the appointment of the Prosecutor of the International Tribunal, the Commission of Experts established pursuant to resolution 780 (1992) should continue on an urgent basis the collection of information relating to evidence of grave breaches of the Geneva Conventions and other violations of international humanitarian law as proposed in its interim report'. As well as confirming the Council's confidence in the work of the Commission of Experts, this also confirmed the vital relationship between the Commission and the Tribunal. Cherif Bassiouni would later describe the Commission of Experts as 'the first stage in the establishment of the Tribunal'.

Frits Kalshoven resigned from the Commission of Experts in September 1993, openly protesting the lack of political support from major governments, including France and the United Kingdom. He pointed to the failure to provide any logistical or financial assisting, complaining that it was unacceptable for the security Council to vote to create a body and then deny it the means to implement its decision. Regrettably, nearly a quarter of a century later, the problem persists. A few weeks after Kalshoven's gesture, the Norwegian member of the Commission, 
Torkel Opsahl, died suddenly.

But far from withering under the impact of these two blows, as some cynical observers predicted at the time, the Commission was suddenly invigorated by the appointment of Cherif Bassiouni as chairman. It was in many ways the finest hour for the great Egyptian international lawyer, who had done so much throughout his career of many decades to keep the flame of international justice alight. Polyglot and polymath, Bassiouni had been teaching international law at DePaul University in Chicago since the 1960s. In the early 1970s, he took on the leadership of the International Institute of Higher Studies in Criminal Sciences, known since 2016 as the Siracusa Institute. Over the years, international experts gathered periodically for conferences and expert panels at the Institute's seat in Siracusa, on the Italian island of Sicily, to discuss and debate issues of international criminal law and human rights.

Bassiouni immediately took steps to address the funding challenges, defying the entreaties of senior lawyers within the United Nations system. He also enlisted pro bono professionals and legions of law students who were thrilled to direct their energies to real problems in one of the world's great crises. By early 1994, the Commission had collected some 65,000 documents which were catalogued and organised in a data base located in Chicago, as well as a computerized archive comprising hundreds of hours of testimony.

Another Commissioner, William Fenrick of Canada, directed a series of thirty-four field investigations. These included the excavation of several mass graves in the conflict region. Later, Fenrick migrated to the International Criminal Tribunal, together with one of his deputies on the Commission of Experts, Payam Akhavan. Both became valued senior staff members of the Office of the Prosecutor in the early days of its activities. In this way, much of the institutional memory and expertise of the Commission, acquired before the Tribunal existed but 
principally during the first year when it was not fully functional, was informally transferred to the Tribunal.

The Commission was also energized by the addition of two women members, appointed to replace Kaltshoven and Opsahl. Dutch legal academic christine cleirin took charge of investigations into rape and sexual assault, directing a team of forty women lawyers, psychologists and interpreters. More than 200 victims or witnesses to sexual and gender-based violence were interviewed by the Commission. Hanne Sophie Greve, a Norwegian judge, conducted an investigation into the ethnic cleansing of Prijedor, something that was later documented in the judgments of the International Criminal Tribunal for the former Yugoslavia. When Prosecutor Richard Goldstone initiated proceedings against Tadić in November 1994, the written application relied upon evidence gathered by the Commission of Experts.

In the case law of the Tribunal itself, the Commission seems to have made more of a mark for its legal conclusions and analysis than for its very substantial factual findings. Perhaps that is because the Commission's report could not readily have been admissible as evidence. The facts it uncovered had to be subject to independent proof during the trials. On the other hand, the views of the Commission of Experts on matters like command responsibility, a notion about which the post-Second World War proceedings were rather thin, proved both helpful and persuasive. The doctrine of command responsibility, set out in article 7 of the statute of the Tribunal permits the conviction of a military and even a civilian superior for the acts of subordinates to the extent that the superior should have known that the crimes might be committed. The Commission's conclusions about the admissibility of circumstantial evidence and the mental element of international criminality also influenced the case law of the Tribunal.

In December 1993, the Commission was informed by the Legal 
Advisor to the Secretary-General that its mandate was to conclude at the end of April 1994, a ruling that was inconsistent with the security Council's instruction that the commission continue its work until a Prosecutor was appointed. In a technical sense, a Prosecutor had been appointed by then, although he never really took up the job. The fledgling office had to await the arrival of Richard Goldstone, in July 1994.

Welcoming its final report and the voluminous annexes, Secretary-General Boutros-Ghali said: 'The material and information collected and recorded in the data base, now transferred to the Tribunal, will not only assist in the prosecution of persons responsible for serious violations of international humanitarian law, but will constitute a permanent documentary record of the crimes committed in the former Yugoslavia, and thus remain the memorial for the hundreds of thousands of its innocent victims.' Amen. 